\title{
Distance teaching: perceived stress, psychological health and work satisfaction among classroom teachers
}

\author{
Janja Tekavc, Pia Novak \\ University of Maribor, Faculty of Education, Koroška cesta 160, Maribor, Slovenia \\ janja.tekavc@um.si; pia.novak@student.um.si
}

\begin{abstract}
Ninety-one Slovenian classroom teachers participated in a study and completed an online questionnaire about their perceived level of stress, wellbeing and work satisfaction during the period of distance teaching due to epidemic of COVID-19. The results revealed that teachers perceived similar amount of work-related stress during the period of distance teaching as in general classroom setting. The majority of teachers experienced none to minor symptoms of psychological distress due to distance teaching working conditions, and reported being predominantly satisfied with their work during the epidemic of COVID-19.
\end{abstract}

Keywords: COVID-19, distance work, teaching, psychological distress, wellbeing

\section{Introduction}

The pandemic of COVID-19 is presenting us with "uncertain times," in which the future of an individual as well as the whole society presents as unclear. The pandemic emerges as a stressful and even traumatic event that requires individuals to make sense of the new situation and choose appropriate coping actions. Psychological theories and research on stress and individual coping are of great relevance to understand individual responses and reactions to merging stressors associated with the COVID-19 pandemic (Guan et al., 2020).

The influence of the pandemic of COVID-19 has represented a career transition to many people (Rudolph and Zacher, 2020). During the epidemic of COVID-19, the majority of the Slovenian active population encountered a changed way of working. Among them were also Slovenian teachers who carried out distance teaching during the measures introduced in the fight against 
the spread of the COVID-19 virus. Teachers' work is in general associated with increased level of stress, especially when teachers are exposed to many changes in the work process (De Simone et al., 2016). Research shows that teachers' perceived stress is consistently correlated with their wellbeing. Further, teachers' perceptions of stress and sense of wellbeing are central to their ability to teach well (MacIntyre et al., 2019).

The aim of this research was to assess the perceived level of current and general stress in classroom teachers during the period of distance teaching due to COVID-19, their psychological wellbeing, and the level of satisfaction with their work.

\section{Methods}

\section{Participants and procedure}

An invitation to an online questionnaire was sent to primary school teachers via social network groups (i.e., Facebook, Twitter) at the beginning of sixth week of online teaching, which represented the middle of the work-at-home period for teachers in Slovenia during COVID-19 epidemics. The online questionnaire was developed on previous qualitative data inquiry (i.e. interviews with several teachers) and included: demographic questions, information about the current level of perceived stress during distance online teaching, general stress during previous periods of teaching, current distress and psychological wellbeing markers, and satisfaction with life and work. Ninety-one Slovene female teachers completed an online questionnaire. The mean age of participants was 40.90 years $(S D=19.26)$ and the participants had a mean of 13.66 years of teaching experience $(\mathrm{SD}=9.85)$.

\section{Measures}

We used the following measures: (1) Demographic and background information: participants' age, seniority in primary school teaching, the grade they currently teach, and the number of students they currently have in their class; (2) Perceived psychological stress: we used single-item measures of stress to capture the extent to which participants reported experiencing stress during the period of distance learning (i.e., current stress) as well as their typical level of stress during traditional classroom teaching (i.e., general stress); (3) Current distress symptoms: using scales that ranged from 1 (not at all) to 4 (very much), the participants reported the extent to which they were experiencing different psychological distress symptoms; (4) Work satisfaction: using a scale that ranged from 1 (not at all) to 5 (very much), the participants indicated the extent of their satisfaction with their current work and private life. 


\section{Statistical methods}

General descriptive statistical analysis using the statistical program SPSS version 26 was used to evaluate the data. Paired samples $t$-tests were performed to examine differences between current and general stress with two-tailed tests of significance and confidence intervals being based on the level of $p<.05$.

\section{Results}

In the present study, participants reported very similar scores for current stress $(\mathrm{M}=3.10, \mathrm{SD}=0.60)$ and for general stress $(\mathrm{M}=3.11, \mathrm{SD}=0.50 ; \mathrm{t}[91]=-0.86$, $\mathrm{p}=.39)$.

Table 1: Teachers' experience of psychological distress symptoms during the period of distance teaching.

\begin{tabular}{|c|c|c|c|c|c|c|}
\hline \multirow[b]{2}{*}{ Psychological distress symptoms } & \multicolumn{4}{|c|}{ Frequency (\%) } & \multirow[b]{2}{*}{$M$} & \multirow[b]{2}{*}{$S D$} \\
\hline & 1 - Never & $\begin{array}{c}2 \text {-Occasion- } \\
\text { ally }\end{array}$ & 3-Often & $\begin{array}{c}4 \text { - Very of- } \\
\text { ten / all- } \\
\text { ways }\end{array}$ & & \\
\hline Restlessness & 14 & 49 & 19 & 17 & 2.4 & 0.93 \\
\hline Mouth dryness & 41 & 44 & 9 & 6 & 1.8 & 0.85 \\
\hline Absence of positive feelings & 48 & 34 & 12 & 5 & 1.7 & 0.87 \\
\hline Breathing issues & 66 & 23 & 8 & 4 & 1.5 & 0.82 \\
\hline Lack of proactivity & 54 & 35 & 10 & 1 & 1.6 & 0.71 \\
\hline Overacting & 22 & 48 & 17 & 13 & 2.2 & 0.93 \\
\hline Shaking & 76 & 14 & 8 & 2 & 1.4 & 0.72 \\
\hline Nervousness & 28 & 38 & 19 & 15 & 2.2 & 1.02 \\
\hline Concern & 51 & 35 & 8 & 6 & 1.7 & 0.87 \\
\hline Nothing to be happy about & 59 & 27 & 8 & 6 & 1.6 & 0.89 \\
\hline Irritation & 20 & 41 & 22 & 17 & 2.4 & 1.00 \\
\hline Tension, hard to relax & 18 & 47 & 23 & 12 & 2.3 & 0.90 \\
\hline Sadness & 31 & 43 & 15 & 11 & 2.1 & 0.95 \\
\hline Impatience & 28 & 38 & 24 & 11 & 2.2 & 0.96 \\
\hline Anxiety & 53 & 28 & 14 & 5 & 1.7 & 0.90 \\
\hline Lack of enthusiasm & 58 & 28 & 9 & 5 & 1.6 & 0.86 \\
\hline Feelings of worthlessness & 56 & 29 & 9 & 6 & 1.7 & 0.89 \\
\hline Oversensitiveness & 19 & 40 & 30 & 11 & 2.3 & 0.91 \\
\hline Increased heart rate & 48 & 31 & 17 & 3 & 1.8 & 0.86 \\
\hline Fear & 44 & 38 & 14 & 4 & 1.8 & 0.85 \\
\hline Feelings of meaningless & 78 & 13 & 5 & 3 & 1.3 & 0.73 \\
\hline
\end{tabular}

Table 1 presents different symptoms which usually appear with experiencing a psychological distress and the extent to which participants rated their observation of the occurrence of these symptoms among themselves during the period of distance teaching. On a scale ranging from 1 (not at all) to 4 (very much), the arithmetic means of the symptoms ranged from the minimum of 
1.3 to the maximum of 2.4. The symptoms with the highest mean are indicated in the table.

Participants' level of satisfaction with different aspects of their work and private life during the period of distance teaching is presented in Table 2. On a scale ranging from 1 (very dissatisfied) to 5 (very satisfied), the arithmetic means of the dimensions ranged from the minimum of 2.6 to the maximum of 4.2. The participants indicated the highest level of satisfaction with quality of learning materials they provided for their students during the period of distance teaching, the availability of the working materials they needed for their work at home, and their communication with the students and their parents. They were least satisfied with the amount of time they dedicated for their work as well as for their private life.

Table 2: Teachers' level of satisfaction with work and life during the period of distance teaching.

\begin{tabular}{|c|c|c|c|c|c|c|c|}
\hline \multirow{2}{*}{ Dimension } & \multicolumn{5}{|c|}{ Level of satisfaction (frequency \%) } & \multirow{2}{*}{$M$} & \multirow{2}{*}{$S D$} \\
\hline & 1 & 2 & 3 & 4 & 5 & & \\
\hline Quality of work & 2 & 14 & 25 & 47 & 11 & 3.5 & 0.95 \\
\hline Teaching approach & 3 & 15 & 30 & 42 & 10 & 3.4 & 0.98 \\
\hline Availability of working materials & $\mathrm{o}$ & 2 & 8 & 65 & 25 & 4.1 & 0.64 \\
\hline Quality of learning materials & $\mathrm{o}$ & $\mathrm{o}$ & 7 & 64 & 30 & 4.2 & 0.56 \\
\hline Private life & 7 & 23 & 27 & 29 & 14 & 3.2 & 1.15 \\
\hline Time dedicated for work & 20 & 34 & 21 & 21 & 4 & 2.6 & 1.16 \\
\hline Time dedicated for private life & 19 & 34 & 18 & 23 & 7 & 2.6 & 1.21 \\
\hline Personal relationships & 9 & 19 & 20 & 30 & 23 & 3.4 & 1.27 \\
\hline Partner and family support & 3 & 7 & 13 & 46 & 31 & 3.9 & 1.00 \\
\hline Communication with co-workers & o & 5 & 19 & 53 & 23 & 3.9 & 0.80 \\
\hline $\begin{array}{l}\text { Communication with students } \\
\text { and parents }\end{array}$ & o & 3 & 20 & 49 & 27 & 4 & 0.78 \\
\hline
\end{tabular}

Legend: $M$, Mean; SD, Standard deviation

Level of satisfaction ... 1-very dissatisfied, 2 - dissatisfied, 3 - not satisfied, not dissatisfied, 4 - satisfied, 5 - very satisfied

\section{Discussion}

The purpose of the present study was to investigate primary school teachers' perceived level of stress, wellbeing and satisfaction with their work and life during the period of distance teaching due to epidemic of COVID-19. The results revealed a similar level of perceived stress between general teaching setting and distance learning conditions. This is somewhat different from the study findings of the Slovene National Education Institute about distance education during epidemic of COVID-19 (2020), in which teachers reported perceiving distance teaching as stressful and demanding.

The majority of teachers in our study reported never or only occasionally experiencing different symptoms of psychological distress during the period of distance teaching. This is in line with some foreign studies (See, Wardle 
and Collie, 2020) in which the majority of teachers reported being happy and cheerful, calm and relaxed during the period of distance teaching due to lockdown. Despite the fact that distance teaching was not connected to significant psychological distress for the majority of participants in our study, we found that among the most common symptoms of psychological distress were different signs of increased nervous tension (e.g., restlessness, nervousness, irritation, and inability to relax), which implies that for some teachers the whole situation of working at home was however demanding. The difficultness of this situation is probably connected not only to their changed working conditions, but also to changes in teachers' private home settings as a consequence of their confinement in their home because of the epidemic (e.g., taking care of their children's school work, having their spouse working at home in the same time).

In general, teachers in our sample reported being satisfied with their working conditions, private life, and social support they received during the epidemic of COVID-19. They seemed to be the most satisfied with the availability of materials they were able to reach by using information communication technologies (ICTs), the materials they provided for their students, as well as with their communication with students and their parents. We could argue that the situation with COVID-19 allowed the teachers to get acquainted with information communication technologies (ICTs) and strengthen their competencies in their use. Participants in our study appeared the least satisfied with the amount of time they dedicated for their work and private life, with spending too much time for their work and as a consequence being left with inadequate time for themselves. This supports the notion that the influence of the pandemic of COVID-19 has represented a career transition to many people (Rudolph and Zacher, 2020) including teachers, forcing them to face and invest time and energy to adapt to the new working demands.

This study offers a very important and current insight into teachers' coping with changed working conditions due to epidemic of COVID-19. However, some weaknesses can be identified, such as (1) small sample of participants; (2) participants were invited to participate via social networks, which could represent the fact that mostly of the teachers who are very skilled in using ICTs were involved in this study; (3) time of data gathering (i.e., sixth week of distance teaching) in which the majority of teachers might have already successfully managed the transition from face-to-face teaching to distance teaching.

\section{Conclusions}

In light with preparing for the possible upcoming outbreaks of COVID-19 and changed educational settings, this study offers some valuable insight into teachers' perceptions of distance teaching and its impact on their health and wellbeing. Despite representing a transition which required an active adaptation, the period of distance teaching due to epidemic of COVID-19 did not appear as a significantly stressful situation for teachers in our study. Participants 
reported facing only minor or no psychological symptoms of distress and in general experienced satisfaction with their work and life during the pandemic. In order to more thoroughly investigate the impacts of distance teaching on teachers and design its optimal procedures, future research is needed, including larger and more representative sample of teachers, longitudinal approach, and other methods of inquiry (e.g., qualitative approach).

\section{References}

DE SIMONE, S., CICOTTO, G., \& LAMPIS, J., 2016. Occupational stress, job satisfaction and physical health in teachers. European Review of Applied Psychology, vol. 66, no. 2, pp. 65-77.

GUAN, Y., DENG, H., \& ZHOU, X., 2020. Understanding the impact of the COVID-19 pandemic on career development: Insights from cultural psychology. Journal of Vocational Behavior, [viewed 27 June 2020]. Available from: https://pubmed.ncbi.nlm.nih.gov/32382162/

MACINTYRE, P. D., ROSS, J., TALBOT, K., MERCER, S., GREGERSEN, T., \& BANGA, C. A., 2019. Stressors, personality and wellbeing among language teachers. System, vol. 82, pp. 26-38.

RUDOLPH, C. W., \& ZACHER, H., 2020. COVID-19 and careers: On the futility of generational explanations. Journal of Vocational Behavior, [viewed 27 June 2020]. Available from: https://pubmed.ncbi.nlm.nih.gov/32390654/

SEE, B. H., WARDLE, L., \& COLLIE, P. (2020). 'Teachers' wellbeing and workload during Covid-19 lockdown.' Working paper. [viewed 27 June 2020]. Available from: http://dro.dur.ac.uk/31114/1/31114.pdf?DDD29+vqhv43

ZAVOD REPUBLIKE SLOVENIJE ZA ŠOLSTVO, 2020. Analiza izobraževanja na daljavo v času epidemije Covid-19 v Sloveniji. Delno poročilo. [viewed 20 July 2020]. Available from: https://www.zrss.si/digitalnaknjiznica/IzobrazevanjeNaDaljavo/10o/ 